\title{
First evidence showing that Pepper vein yellows virus P4 protein is a movement protein
}

\author{
Sangsang $\mathrm{Li}^{1 \dagger}$, Xianyan $\mathrm{Su}^{2 \dagger}$, Xiangwen Luo ${ }^{3}$, Yu Zhang ${ }^{1}$, Deyong Zhang ${ }^{1,3}$, Jiao Du ${ }^{3}$, Zhanhong Zhang ${ }^{3}$, \\ Xian OuYang ${ }^{3}$, Songbai Zhang ${ }^{1,3^{*}}$ and Yong Liu, ${ }^{1,3^{*}}$
}

\begin{abstract}
Background: Plant viruses move through plasmodesmata (PD) to infect new cells. To overcome the PD barrier, plant viruses have developed specific protein(s) to guide their genomic RNAs or DNAs to path through the PD.

Results: In the present study, we analyzed the function of Pepper vein yellows virus P4 protein. Our bioinformatic analysis using five commonly used algorithms showed that the P4 protein contains an transmembrane domain, encompassing the amino acid residue 117-138. The subcellular localization of P4 protein was found to target PD and form small punctates near walls. The P4 deletion mutant or the substitution mutant constructed by overlap PCR lost their function to produce punctates near the walls inside the fluorescent loci. The P4-YFP fusion was found to move from cell to cell in infiltrated leaves, and P4 could complement Cucumber mosaic virus movement protein deficiency mutant to move between cells.
\end{abstract}

Conclusion: Taking together, we consider that the P4 protein is a movement protein of Pepper vein yellows virus.

Keywords: Pepper vein yellows virus, P4 protein, Plasmodesmata, Movement protein, Cell-to-cell movement

\section{Background}

Plasmodesmata-mediated macromolecular trafficking is critical for plant growth and development [1]. Plant viruses have been shown to traffic between host cells through plasmodesmata (PD), and such trafficking is crucial for viral systemic infection [2].

PD is considered as a bottleneck for plant virus infection in plant, due mainly to its size exclusion limit (SEL) and/or the intricate and dynamic regulations controlled by the host defense mechanism [3]. To overcome this bottleneck, plant viruses have evolved to encode movement protein(s) (MP) to facilitate their intracellular trafficking, in a form of viral replication complexes or viral

\footnotetext{
* Correspondence: zsongb@hotmail.com; haoasliu@163.com

'Sangsang Li and Xianyan Su contributed equally to this work.

${ }^{1}$ Longping Branch, Hunan University, Changsha 410125, China

Full list of author information is available at the end of the article
}

particle [4]. The MPs produced by plant viruses are strikingly different [5]. The pioneer report of viral MP is the $30 \mathrm{kDa}$ MP of Tobacco mosaic virus (TMV), this MP was considered to guide TMV virion to move between cells [6], and its domain of 19 amino acids (195 to 213) is essential for localization of the MP to the cell wall fraction of plant cells [7]. Similarly as TMV, the Ourmiaviruses also encoded a $30 \mathrm{~K}$ movement protein to guide virus movement in plant cells [8]. The second type of MPs have two or three specialized MPs, and are referred to as double or triple gene block proteins (DGBps and TGBps) [9], which form polyprotein to localize to the periphery of the plant cells [10]. The third type of MPs are low molecule MPs, such as NSm encoded by Tomato spotted wilt tospovirus (TSWV) [11]. The transmembrane dispositon of low molecule movement protein of Prunus necrotic ringspot virus (PNRSV) is

(c) The Author(s). 2020 Open Access This article is licensed under a Creative Commons Attribution 4.0 International License, which permits use, sharing, adaptation, distribution and reproduction in any medium or format, as long as you give appropriate credit to the original author(s) and the source, provide a link to the Creative Commons licence, and indicate if changes were made. The images or other third party material in this article are included in the article's Creative Commons licence, unless indicated otherwise in a credit line to the material. If material is not included in the article's Creative Commons licence and your intended use is not permitted by statutory regulation or exceeds the permitted use, you will need to obtain permission directly from the copyright holder. To view a copy of this licence, visit http://creativecommons.org/licenses/by/4.0/. The Creative Commons Public Domain Dedication waiver (http://creativecommons.org/publicdomain/zero/1.0/) applies to the data made available in this article, unless otherwise stated in a credit line to the data. 
essential for its membrane localization, however, is not indispensable for virus cell-to-cell movement [12].

Pepper vein yellows virus (PeVYV), a new member in the genus Polerovirus, family Luteoviridae, was reported to infect multiple important solanaceous crops in Europe [13], Asia [14] and Africa [15]. Although the P4 protein of PeVYV was recently reported as a viral movement protein, based on the bioinformatic comparison to the genome structure of the movement protein of the type Potato leafroll virus species (PLRV) [16], the biological function and the key domain of $\mathrm{P} 4$ protein needed for PD traffiking remained unknown.

In the present study, we intend to determine the key domain needed for the interaction between the P4 protein and PD, and the capacity of P4 protein complementing Cucumber mosaic virus movement protein deficiency mutant to move between cells.

\section{Results}

\section{P4 protein construction}

Membrane association and plasmodesmata targeting are crucial functions of viral movement proteins. To investigate domain(s) in the P4 protein that are responsible for membrane association, we first predicted transmembrane (TM) domain(s) in the P4 protein using several bioinformatics algorithms. Results shown in Fig. S1 revealed two potential TM domains in the P4 protein. Both DAS and TMpred algorithms showed that the P4 protein was an integral membrane protein and the two predicted TM domains were located at a region encompassing aa residue
127-129 (by DAS algorithm) and aa residue 117-138 (by TMpred algorithm), respectively.

\section{P4 protein targets PD of host cells}

To determine whether the P4 protein could target plasmodesmata in cell walls, we first infiltrated $N$. benthamiana leaves with $A$. tumefaciens cultures carrying the pP4-YFP or pPDLP8-YFP plasmid. The infiltrated leaves were harvested at $48 \mathrm{hpi}$ and then examined for the intracellular localization patterns of the two fusion proteins by Confocal Microscopy. The result showed that the P4-YFP fusion protein accumulated as yellow fluorescence punctates in the cytoplasm and near the cell walls (Fig. 1, upper panel, red arrows showed). The PD-YFP fusion protein was found to produce small yellow fluorescence punctates near the cell walls, but not large punctates in the cytoplasm like the P4-YFP (Fig. 1, lower panel).

To confirm if the computer-predicted TM domains in the $\mathrm{P} 4$ protein had the ability to target plasmodesmata, we fused the P4 mutants $\Delta \mathrm{P} 4^{117-138}$ and $\Delta \mathrm{P} 4^{\mathrm{AAA} 117-138}$ to YFP, respectively, and expressed them in $N$ benthamiana leaves. By $48 \mathrm{hpi}$, the infiltrated leaves were harvested and examined under the confocal microscope. The results showed that the yellow fluorescence from the $\Delta \mathrm{P} 4^{117-138}$-YFP fusion or from the $\Delta \mathrm{P} 4^{\mathrm{AAA} 117-138}$. YFP fusion was near cell walls, but no yellow punctates were observed in the cell walls, reminiscent of PD localization (Fig. 2). The co-localization of P4 or its mutants with PDLP8 (marker protein localized in PD) showed that only P4 could target PD (Fig. 3).
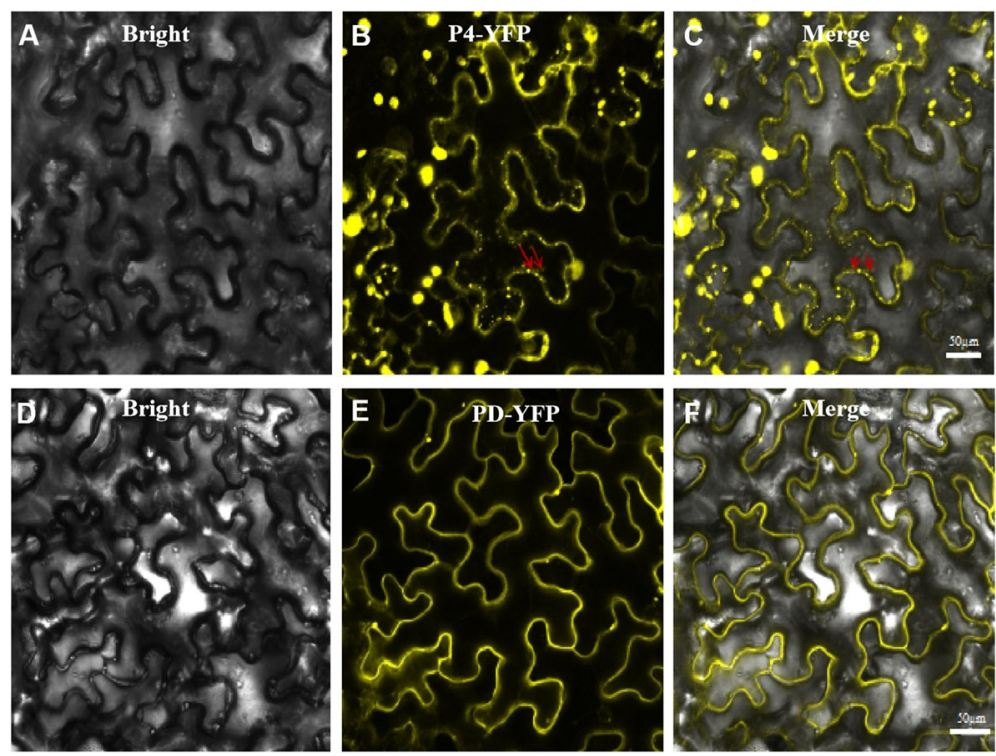

Fig. 1 Subcellular localization patterns of P4-YFP and PD-YFP. Nicotiana benthamiana leaves were infiltrated with Agrobacterium tumefaciens GV3101 cultures carrying pP4-YFP or pPDLP8-YFP. a-c: P4-YFP subcellular localization; d-f: PD-YFP subcellular localization. Bars, 50 um. Red arrows indicate the small punctures near the cell walls 

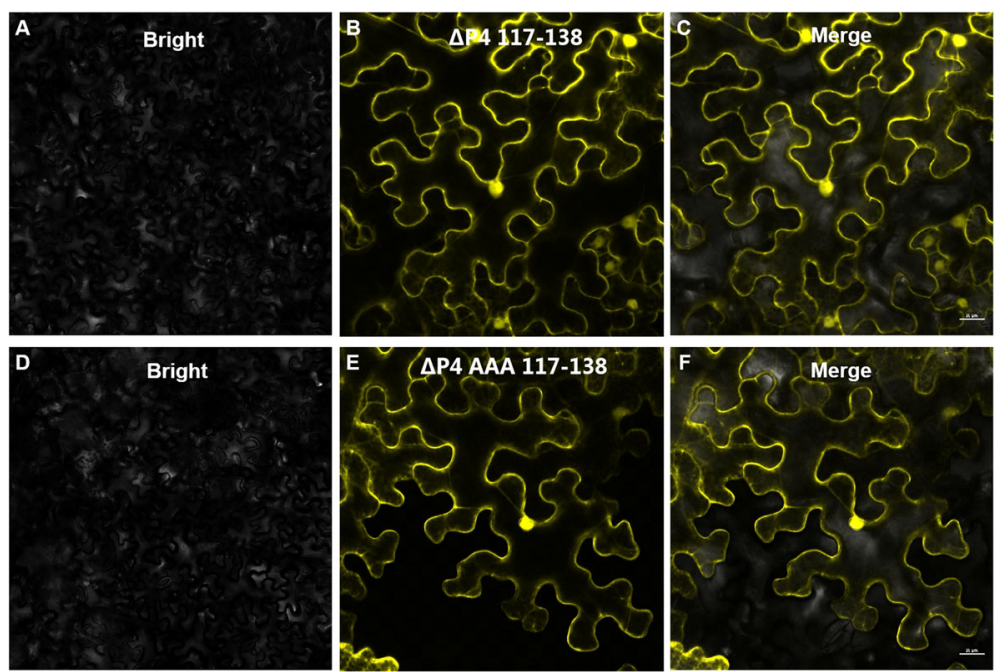

Fig. 2 Subcellular localization patterns of $\triangle P 4^{117-138}-Y F P$ and $\triangle P 4^{A A A 117-138}-Y F P$. N. benthamiana leaves were infiltrated with Agrobacterium tumefaciens GV3101 cultures carrying $\mathrm{p} \triangle \mathrm{P} 4^{117-138}$-YFP or $\mathrm{P} \triangle \mathrm{P} 4^{\mathrm{AAA} 117-138}$-YFP. a-c: $\triangle \mathrm{P} 4^{117-138}$-YFP subcellular localization; d-e: $\triangle \mathrm{P} 4^{\mathrm{AAA} 117-138}$-YFP subcellular localization. Bars, $50 \mu \mathrm{m}$

\section{P4 protein functions as movement protein}

To determine whether the P4 protein can move through $\mathrm{PD}$, we infiltrated $N$. benthamiana leaves with A. tumefaciens culture carrying the pP4-YFP plasmid. As a control, we infiltrated $N$. benthamiana leaves with a different culture carrying the pPDLP8-YFP plasmid. A total of 35 fluorescent loci expressing PD-YFP were examined under the confocal microscope at $24 \mathrm{hpi}$ and the PD-YFP fusion was found in single cells only (Fig. S2 and Table S2). At the same time point, the P4-YFP fusion in 21 of the 23 fluorescent signals had trafficked through the PD and entered the neighboring cells.

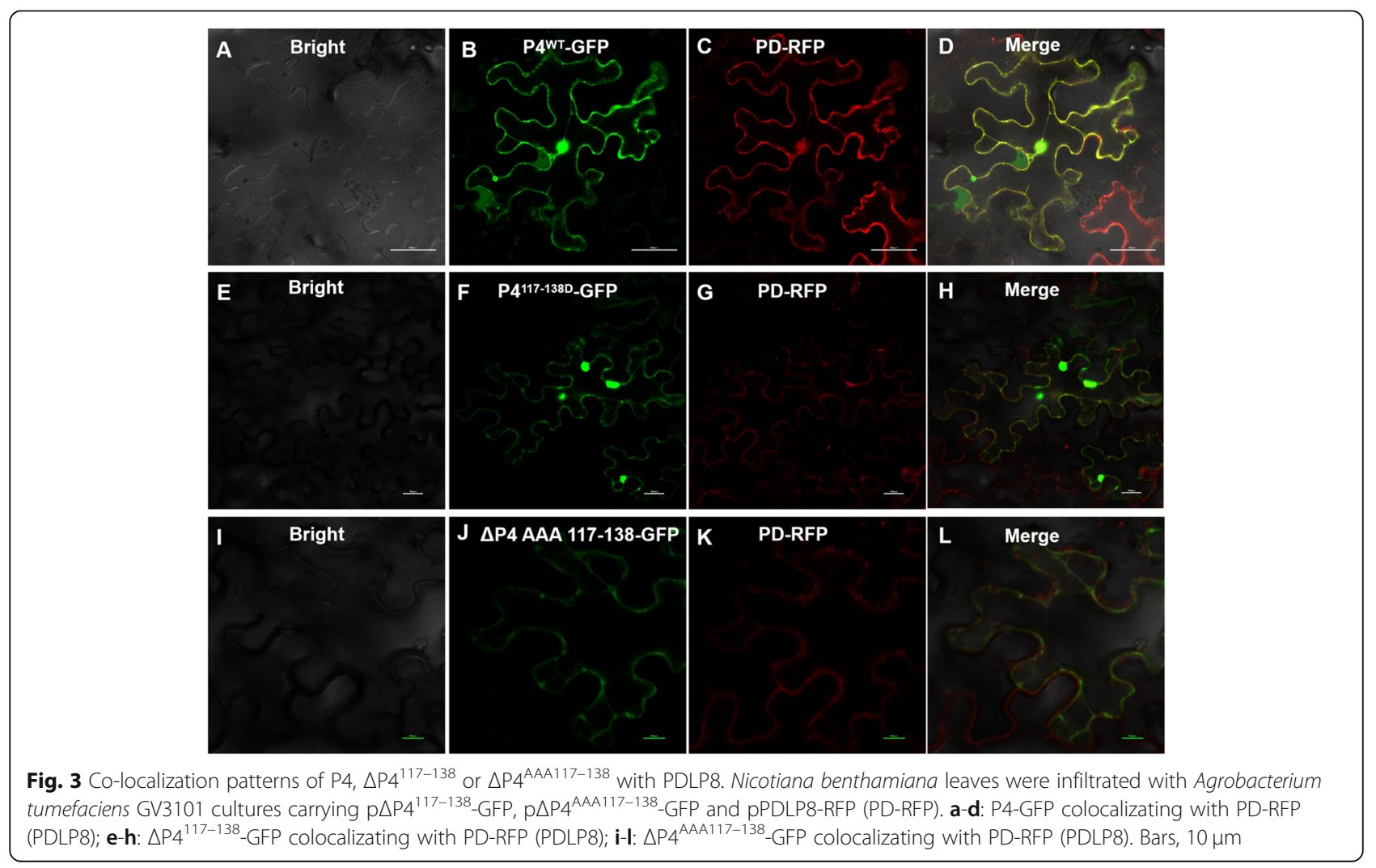


To further determine whether the $\mathrm{P} 4$ protein functions as movement protein to drive virus cell-to cell moving through PD, we infiltrated $N$. benthamiana leaves with A. tumefaciens culture carrying the plasmid of $\mathrm{P} 4$ or its mutants and CMV infectious clone with its movement protein 3a replaced by GFP. As a control, we infiltrated $N$. benthamiana leaves with a different culture carrying the plasmid of expressing P4 and its mutants. As Fig. 4 shown, $\mathrm{P} 4$, not $\mathrm{P} 4$ mutants could drive Cucumber mosaic virus movement protein deficiency mutant cell-tocell moving through PD. A total of 46 of the 50 fluorescent signals expressing P4-GFP and CMV movement protein deficiency mutant were examined under the confocal microscope at $6 \mathrm{dpi}$, and the P4 mutants was found in single cells only or less than $16 \%$ virus entered the neighboring cells (Fig. 4 and Table 1).

\section{Discussion}

It is well documented that different plant viruses encode different movement proteins (MPs) to traffic through PD between two cells $[6,9,11]$. For example, the $17 \mathrm{kDa}$ movement protein of Potato leafroll virus (PLRV, genus Polenovirus, family Luteoviridae), was reported as a low molecular weight movement protein of PLRV [17]. In the present study, the PeVYV P4 protein $(17.5 \mathrm{kDa})$, which was previously predicted as a virus movement protein, was analyzed and found to localize to PD in cell walls. A domain encompassing amino acid residues $117-138$ in the P4 protein was determined to have an ability to target PDs.

The P4-YFP fusion protein was found to traffic between epidermal cells, and P4 could complement heterological Cucumber mosaic virus movement protein deficiency mutant to move between cells. These results provided the first evidence showing that the PeVYV $17.5 \mathrm{kDa}$ protein is a viral MP.

Interestingly, in the $N$. benthamiana leaf epidermal cells expressing P4-YFP fusion protein, large and small yellow fluorescent punctates were observed (Fig. 2). Previous studies have shown that many viruses can produce aggregates during their infection in plant and these aggregates may have multiple functions including preventions of degradations by host cellular machinery [18] and/or providing viral and host factors for virus replication [19]. So the large punctates were found in cytoplasm and the small punctates were found near the cell walls.

\section{$\mathbf{A}$}

Vector

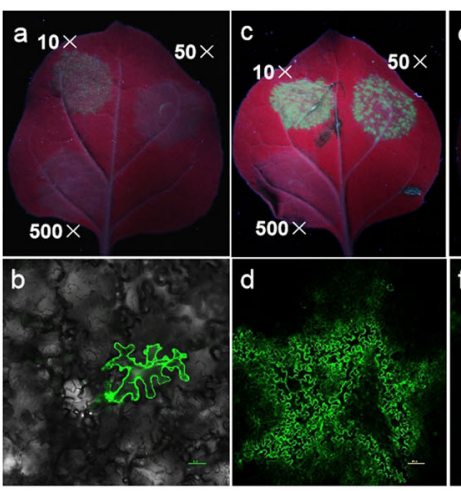

P4

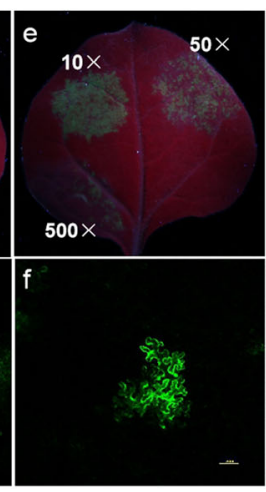

$\triangle P 4$ AAA 117-138 $\triangle P 4$ 117-138
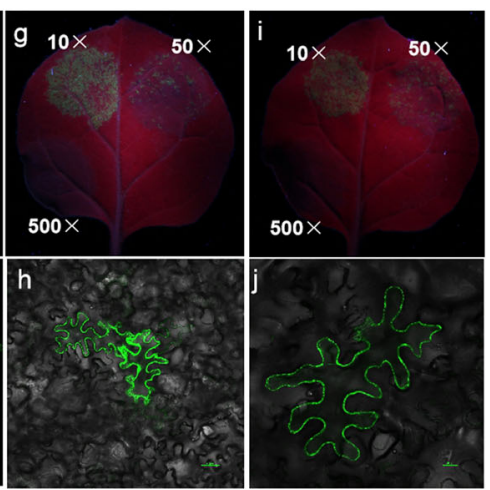

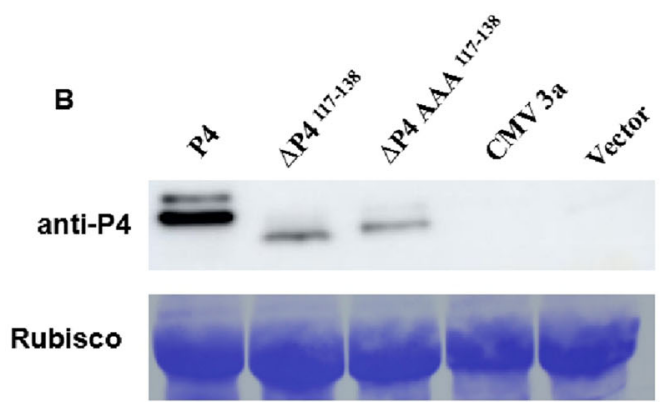

Fig. 4 The P4 could complement movement capacity of Cucumber mosaic virus movement protein deficiency mutant between epidermal cells in N. benthamiana leaves. a: Nicotiana benthamiana leaves were infiltrated with Agrobacterium tumefaciens GV3101 cultures (10,50 or 500 fold dilution of OD600 = 1.0); a, c, e, g, i: Complementary tests of P4 or its mutants and Cucumber mosaic virus movement protein deficiency mutant under UV light; $b, d, f, h$, j: Complementary tests of P4 or its mutants and Cucumber mosaic virus movement protein deficiency mutant under a confocal microscope (Bars, $10 \mu \mathrm{m}$ or $20 \mu \mathrm{m}$ ). $\mathbf{b}$ : Western blotting detection of P4 and its mutants expressed in epidermal cells of $\mathrm{N}$. benthamiana leaves 
Table 1 Movement of PeVY P4 between epidermal cells in N. benthamiana leaves at 6 dpi

\begin{tabular}{|c|c|c|c|c|}
\hline Constructs & No. of loci examined & No. of loci with a single cell (\%) & No. of loci with more than 2 cells (\%) & $\rho$-value \\
\hline Vector & 50 & $50^{a}(100 \%)$ & 0 & \\
\hline$C M V 3^{\mathrm{a}}$ & 50 & 0 & $50(100 \%)$ & \\
\hline P4 & 50 & $4(8 \%)$ & $46(92 \%)$ & $<0.05^{\mathrm{b}}$ \\
\hline$\Delta \mathrm{P} 4$ 117-138 & 50 & $50(100 \%)$ & 0 & \\
\hline$\triangle \mathrm{P} 4 \mathrm{AAA} 117-138$ & 50 & $42(84 \%)$ & $8(16 \%)$ & $<0.05$ \\
\hline
\end{tabular}

${ }^{a}$ Loci with signal cells expressing GFP fluorescence

${ }^{\mathrm{b}} \rho$-value was determined using the unpaired two-tailed Student $t$-test

\section{Conclusion}

The results presented here demonstrated that the 17.5 $\mathrm{kDa}$ protein of PeVYV is a movement protein of the virus. Whether this protein also has a role in virus replication and/or counteraction of host defense machinery requires further investigation.

\section{Methods \\ Plants}

Nicotiana benthamiana plants were grown inside a culture room set at $25^{\circ} \mathrm{C}$ with a $16 \mathrm{~h} \mathrm{light} / 8 \mathrm{~h}$ dark illumination. The seeds of $N$. benthamiana, which is a laboratory cultivar were obtained from The Plant Virology Laboratory of Ningbo University, Ningbo, China and stored in our lab. When the plants reached six-eight weeks old, they were infiltrated individually with one of the agrobacterium cultures made in this study.

\section{P4 protein construction prediction}

Transmembrane (TM) domain inside the P4 protein was predicted using five commonly used methods available on Internet: DAS (http://www.sbc.su.se/miklos/DAS), HMMTOP (http://www.enzim.hu/hmmtop/), TMpred (https://embnet.vital-it.ch/software/TMPRED_form.html), Split (http://split.pmfst.hr/split/4), and Topcons (http:// topcons.cbr.su.se).

\section{Plasmid constructs and agroinfiltration}

Full length PeVYV P4 gene and its alanine substitution mutant or deletion mutant aa position (117-138) were constructed individually through overlap PCR using primers listed in Table S1. The wild type (WT) P4 and its mutants were cloned into expression vector pGWB441(YFP) or pGWB505(GFP) using the Gateway technology [20]. Plasmid pPDLP8-YFP and pPDLP8-RFP (marker protein localized in PD) was from a previously described source and was used to localize plasmodesmata in cell walls [21]. These plasmids were introduced individually into Agrobacterium tumefaciens strain GV3101. Agrobacterium cultures containing the corresponding plansmid were grown overnight in a YEP medium ( $10 \mathrm{~g}$ yeast extract, $10 \mathrm{~g}$ Bacto peptone and $5 \mathrm{~g}$ $\mathrm{NaCl}$ in one liter $\mathrm{H}_{2} \mathrm{O}, \mathrm{pH}$ 7.0) supplemented with 100 $\mathrm{mg} / \mathrm{L}$ kanamycin and $50 \mathrm{mg} / \mathrm{L}$ rifampicin. Agrobacterium cells were pelleted and then incubated for 3 hours in an infiltration buffer $\left(10 \mathrm{mM} \mathrm{MgCl}_{2}, 10 \mathrm{mM}\right.$ MES, pH 5.9, and $150 \mu \mathrm{M}$ acetosyringone). The cultures were further diluted to OD600 $=0.2$ and then infiltrated individually into the abaxial side of $N$. benthamiana leaves. The infiltrated plants were again grown at $25^{\circ} \mathrm{C}$ with a $16 \mathrm{~h}$ light/8 h dark illumination.

\section{Western blotting}

Western blotting was operated as previously described [5]. Total protein was separated by electrophoresis in $10 \%$ SDS-PAGE and transferred onto a PVDF membrane. The antigens on the PVDF membrane were detected with polyantibody against PeVYV P4, then incubated by AP-coupled goat anti-mouse IgG (1:5000 dilution; Sigma) and 5-bromo-4-chloro-3-indolylphosphate/nitroblue tetrazolium (NBT/BCIP) staining (Sangon Biotech, Shanghai, China).

\section{YFP, GFP and RFP images}

Agro-infiltrated leaves were detached from the plants and examined for fluorescence from different YFP, GFP or RFP fusion proteins under a Nikon TI-E + C2 confocal laser-scanning microscope (Nikon Microsystems, Watford, United Kingdom). The excitation wavelength was set at $514 \mathrm{~nm}$ for YFP and GFP, and $555 \mathrm{~nm}$ for RFP, and the emission wavelength was set at 520-550 $\mathrm{nm}$ for YFP and GFP, and $583 \mathrm{~nm}$ for RFP. The images presented in the figures are either single image or multilayered images to achieve the maximum signal intensity. The statistics of GFP signals were determined using the unpaired two-tailed Student $t$-test.

\section{Supplementary information}

Supplementary information accompanies this paper at https://doi.org/10. 1186/s12866-020-01758-y.

Additional file 1: Table S1. Primers for constructing P4 and P4 variants expressing vector. Table S2. Movement of PeVY P4 between epidermal cells in $\mathrm{N}$. benthamiana leaves at $24 \mathrm{hpi}$. Figure S1. Transmembrane domains predicted in the PeVY P4 protein by various algorisms. Positions of the predicted transmembrane domains are indicated. Figure S2. The P4-YFP fusion could move between epidermal cells in N. 
benthamiana leaves. $N$. benthamiana leaves were infiltrated with agrobacterium cultures carrying PP4-YFP or PPDLP8-YFP. The infiltrated leaves were harvested at $24 \mathrm{hpi}$ and examined under a confocal microscope. Images showing PDLP8-YFP expression are shown in the lower panel and images showing P4-YFP expression are shown in the upper panel. Bars, $20 \mu \mathrm{m}$.

\section{Abbreviations}

aa: Amino acid; DGBps: Double gene block proteins; PeVY: Pepper vein yellows virus; PD: Plasmodesmata; PLRV: Potato leafroll virus; TGBps: Triple gene block proteins; TM: Transmembrane; TSWV: Tomato spotted wilt tospovirus

\section{Acknowledgments}

We would like to thank Dr. Jian Yang (Ningbo University, Ningbo, China) for technical assistance of experiments of subcellular localization of P4 protein. We would also like to thank Dr. Xiaorong Tao (Nanjing Agricultural University, Nanjing, China) kind gifting the Cucumber mosaic virus infectious clone with its movement protein 3a replaced by GFP.

\section{Authors' contributions}

$\mathrm{SL}, \mathrm{XS}, \mathrm{ZZ}, \mathrm{XO}$ and $\mathrm{XL}$ - Carried the experimental work. YZ, DZ and JD Collected and analyzed the data, SZ and YL, Designed study, guided data interpretation, and wrote the manuscript. All authors approved the manuscript before it was submitted by the corresponding author.

\section{Funding}

This study was financially supported by the National Natural Sciences Foundation of China (31672003 directed to ZZ, 31772133 directed to SZ). Funding bodies had no role in study design, collected data, analysis, or writing.

\section{Availability of data and materials}

All data generated or analyzed during this study are included in this published article and its supplementary information files.

\section{Ethics approval and consent to participate}

Not applicable.

\section{Consent for publication}

Not applicable.

\section{Competing interests}

The authors have declared that no competing interest exists.

\section{Author details}

${ }^{1}$ Longping Branch, Hunan University, Changsha 410125, China. ${ }^{2}$ Plant Protection Institute of Anhui Academy of Agricultural Science, Hefei 230001, China. ${ }^{3}$ Key Laboratory of Pest Management of Horticultural Crop of Hunan Province, Hunan Plant Protection Institute, Hunan Academy of Agricultural Science, No 726 Second Yuanda Road, Furong District, Changsha 410125, Hunan province, P. R. China.

Received: 28 November 2019 Accepted: 20 March 2020

Published online: 30 March 2020

\section{References}

1. Kim I, Zambryski PC. Cell-to-cell communication via plasmodesmata during Arabidopsis embryogenesis. Curr Opin Plant Biol. 2005;8:593-9.

2. Heinlein M. Plasmodesmata: channels for viruses on the move. Methods Mol Biol. 2015;12:25-52.

3. Waigmann E, Ueki S, Trutnyeva K, Citovsky V. The ins and outs of nondestructive cell-to-cell and systemic movement of plant viruses. Crit Rev Plant Sci. 2004;23:195-250.

4. Boevink P, Oparka KJ. Virus-host interactions during movement processes. Plant Physiol. 2005;138:1815-21.

5. Lazarowitz SG, Beachy RN. Viral movement proteins as probes for intracellular and intercellular trafficking in plants. Plant Cell. 1999;11:535-48.

6. Liu C, Nelson RS. The cell biology of tobacco mosaic virus replication and movement. Front Plant Sci. 2013:4:12.
7. Bernaa A, Gafny R, Wolf S, Lucas WJ, Holt CA, Beachy RN. The TMV movement protein: role of the C-terminal 73 amino acids in subcellular localization and function. Virology. 1991;182(2):682-9.

8. Margaria P, Anderson CT, Turina M, Rosa C. Identification of ourmiavirus 30K movement protein amino acid residues involved in symptomatology, viral movement, subcellular localization and tubule formation. Mol Plant Pathol. 2016;17(7):1063-79.

9. Morozov SY, Solovyev AG. Triple gene block: modular design of a multifunctional machine for plant virus movement. J Gen Virol. 2003;84: 1351-66.

10. Lee $\mathrm{SC}, \mathrm{Wu} \mathrm{CH}$, Wang $\mathrm{CW}$. Traffic of a viral movement protein complex to the highly curved tubules of the cortical endoplasmic reticulum. Traffic. 2010;11:912-30

11. Feng ZK, Xue F, Xu M, Chen XJ, Zhao WY, Garcia-Murria MJ, Mingarro I, Liu $Y$, Huang $Y$, Jiang $L$, Zhu $M$, Tao XR. The ER-membrane transport system is critical for intercellular trafficking of the NSm movement protein and tomato spotted wilt tospovirus. PLoS Pathog. 2016;12:e1005443.

12. Martinez-Gil L, Sanchez-Navarro JA, Cruz A, Pallas V, Perez-Gil J, Mingarro I. Plant virus cell-to-cell movement is not dependent on the transmembrane disposition of its movement protein. J Virol. 2009;83(11):5535-43.

13. Rast ATB. Occurrence of pepper yellow vein virus in the Netherlands. Neth J Plant Pathol. 1988:94:311-3.

14. Zhang SB, Zhao ZB, Zhang DY, Liu Y, Luo XW, Liu J, Wu LF, Peng J. First report of pepper vein yellows virus infecting red pepper in mainland China. Plant Dis. 2015;99:1190.

15. Knierim D, Tsai WS, Kenyon L. Analysis of sequences from field samples reveals the presence of the recently described pepper vein yellows virus (genus Polerovirus) in six additional countries. Arch Virol. 2013;158:1337-41.

16. DeBlasio SL, Xu Y, Johnson RS, Rebelo AR, MacCoss MJ, Gray SM, Heck M. The interaction dynamics of two potato leafroll virus movement proteins affects their localization to the outer membranes of mitochondria and plastids. Viruses. 2018;10:E585.

17. Schmitz J, Stussi-Garaud C, Tacke E, Prüfer D, Rohde W, Rohfritsch O. In situ localization of the putative movement protein (pr17) from potato leafroll luteovirus (PLRV) in infected and transgenic potato plants. Virology. 1997; 235(2):311-22.

18. Moshe A, Gorovits R. Virus-induced aggregates in infected cells. Viruses. 2012;4(10):2218-32.

19. Kaido M, Abe K, Mine A, Hyoudou K, Taniguchi T, Taniguchi H, Mise K, Okuno T. GAPDH-A recruits a plant virus movement protein to cortical virus replication complexes to facilitate viral cell-to-cell movement. PLoS Pathog. 2014;10(11):e1004505.

20. Bryksin AV, Matsumura I. Overlap extension PCR cloning: a simple and reliable way to create recombinant plasmids. Biotechniques. 2010;48(6):463-5.

21. Ye ZW, Chen QF, Chye ML. Arabidopsis thaliana acyl-CoA-binding protein ACBP6 interacts with plasmodesmata-located protein PDLP8. Plant Signal Behav. 2017;12(8):e1359365.

\section{Publisher's Note}

Springer Nature remains neutral with regard to jurisdictional claims in published maps and institutional affiliations.

\section{Ready to submit your research? Choose BMC and benefit from:}

- fast, convenient online submission

- thorough peer review by experienced researchers in your field

- rapid publication on acceptance

- support for research data, including large and complex data types

- gold Open Access which fosters wider collaboration and increased citations

- maximum visibility for your research: over $100 \mathrm{M}$ website views per year

At BMC, research is always in progress.

Learn more biomedcentral.com/submission 